\title{
Islamic Business Ethics As A Basic of Policies Facing The Impact of Covid-19 Pandemics
}

\author{
Ratna Sofiana* dan Dini Amalia Rizky \\ Fakultas Ekonomi dan Bisnis, UIN Sunan Kalijaga \\ *Email: ratna.sofiana@uin-suka.ac.id
}

\begin{abstract}
Morals are very important in every action in the life of a Muslim, including in his business activities. In a difficult or happy situation a Muslim must continue to prioritize in order to create the benefit of the whole community. In difficult circumstances such as in early 2020 where the world and Indonesia were shocked by the emergence of the COVID-19 virus which disrupted the health and economy of the country. At such times it is important to review the establishment of policies that can provide welfare for all levels of society both from the government or business actors in accordance with applicable norms and culture. This research. This research was conducted with a literature review method using analysis of secondary data. The results of this study indicate that some requirements that are in accordance with Islamic business ethics must be considered by the government and business actors, namely establishing clear and transparent information platforms, setting standards on business activities and products that are in accordance with health regulations to control the needs of community products, and making public educative.
\end{abstract}

Keywords: pandemic, company policy, regulation, welfare.

\section{PENDAHULUAN}

Islamic business ethics is an attempt to process the correct actions according to Islamic law in carrying out a business that covers production, distribution and service in carrying out company goals (Aziz, 2013). This process is very important to be applied in all situations when a person does business, because the absence of truth in doing business will cause damage such as the accumulation of commodities such as LPG which will cause the community's needs to be disrupted. An event like this happened to cause commodities to experience scarcity and sharply rising prices, of course things like this are not in accordance with the Islamic ethics of running a business. Similar events also occurred in commodity masks that have increased prices by up to 4 times, this is due to the use of the Corona virus issue which is accompanied by shortages and elements of mask hoarders (Alfons, 2020).

End of 2019 the world was shocked by the emergence of a new virus originating from Wuhan, China. The first case began to occur November 17, 2019 This was revealed from government data seen exclusively by the South China Morning Post (SCMP) media which also mentioned at least 266 corona prefix cases that occurred (Budiartie, 2020). This virus quickly spread throughout the world to make a pandemic outbreak, Indonesia is no exception. The virus has infected 37,420 people, with 13,776 cases recovered and 2,091 deaths in Indonesia (Kurni, 2020). Not only does it cause illness and death the effects of the corona virus spread also weaken the Indonesian economy.

The rapid spread of the COVID-19 outbreak in RI certainly had a profound effect on the Indonesian economy. Government policies regarding the appeal of physical distancing, work, study and worship at home, to the prohibition of activities that cause a crowd would certainly make the economic wheel almost stopped (Sugianto, 2020). So many businesses have to close shops and factories. Then how do entrepreneurs maintain their income in the face of a pandemic like this? Of course by changing the strategy of production, marketing and service. However, some of these policies deviate from the principles of business ethics, one of which is the unilateral dismissal of employees and the soaring price of tests. Then how should these entrepreneurs design policies so that they do not oppose customers, employees and themselves? So it is important to do a study on the appropriate application of government and company policies in dealing with a pandemic. 


\section{RESEARCH METHOD}

Data sources used in this study were sourced from scientific journals, books, articles in mass media, as well as statistical data that have concepts that are in accordance with research. and the type of data used in this study is secondary data

The method used in this research is the study of literature, the study of which the object of research in the form of literature works will be used to answer the research problems proposed by the author, in this case is to maintain the economic stability of entrepreneurs / companies by applying Islamic business ethics in doing business amid the COVID-19 virus pandemic. the nature of the study conducted is descriptive analysis that is providing education and understanding to the reader.

\section{RESULT AND ANALYSIS \\ Islamic Business Ethics}

Irham Fahmi (2013) states that business ethics are rules that affirm a business may act and may not act, where the rules can be sourced from written rules or from unwritten rules. And if a business violates these rules, sanctions will be accepted, where the sanctions can be either direct or indirect.

According to Muslich (2004: 9) business ethics can be interpreted as knowledge of the ideal procedures for business management and regulation that takes into account norms and morality that apply universally and economically / socially, and the adoption of norms and morality supports the aims and objectives of business activities. Whereas in Islam Business ethics is an attempt to process the correct actions in accordance with Islamic law in carrying out a business that encompasses production, distribution and service in carrying out company goals (Aziz, 2013).

Djakfar (2012) states that Islamic business ethics are ethical norms based on the Koran and Hadith which must be used as a reference by anyone in their business activities. In the application of the concept of business ethics in general is based on 5 Principles proposed by Muslich (2004: 18-20), namely:

1. The economic principle of the Company is free to have authority in accordance with the field carried out and its implementation with the vision and mission it has in setting company policies must be directed at efforts to develop the company's vision and mission oriented to prosperity, welfare of workers, the community it faces.

2. The principle of honesty Honesty is the most fundamental value in supporting the success of company performance. In relation to the business environment, honesty is oriented to all parties related to business activities. With honesty owned by a company, the people around the company environment will put high trust for the company.

3. The principle of good intentions and no ill intentions This principle is closely related to honesty. Evil acts certainly do not help companies in building public trust, in fact crime in doing business will destroy the company itself. The intention of a goal is seen to be quite transparent is the mission, vision and goals to be achieved from a company.

4. Fair principle This principle encourages companies to behave and behave fairly to business parties related to the business system.

5. The principle of respect for yourself The principle of respect for yourself is a mirror of positive self-appreciation. This begins with respect for others. Maintaining a good name is a recognition of the existence of the company.

Furthermore Hidayah (2015: 39) explained that there is a special function carried out by Islamic business ethics. Explained as follows:

1. Business ethics seeks to find ways to harmonize and harmonize various interests in the business world.

2. Business ethics also has a role to always make changes in awareness for the public about business, especially Islamic business. And the way is usually by providing a new understanding and perspective about business by using the foundation of values of morality and spirituality, which are then summarized in a form called business ethics.

3. Business ethics, especially Islamic business ethics can also play a role in providing a solution to these various modern business problems that are increasingly far from ethical values. In the 
sense that ethical business must truly refer to its main sources namely the Koran and the Sunnah.

\section{Covid Pandemic 19th Plague}

Law No. 4 of 1984 explains the notion of infectious disease outbreaks as an outbreak of an infectious disease in a society where the number of sufferers has significantly increased beyond normal conditions at certain times and regions and can cause havoc disbebekan due to Toxin (chemical \& biology) and due to infection (viruses, bacteria, protozoa and worms).

Fischer (2020) describes a widespread outbreak called an epindemic. Furthermore he also defines Pandemic as an epidemic that has spread. However, some epidemiologists classify the situation as a pandemic only after the disease has survived in some newly exposed areas through local transmission.

Corona virus (Covid-19) is a large family of viruses that cause disease in humans and animals. In humans it usually causes respiratory tract infections, from the usual fu to serious illnesses such as Middle East Respiratory Syndrome (MERS) and Severe Acute Respiratory Syndrome (SARS). This disease mainly spreads among people through respiratory drops from coughing and sneezing (A. Safrizal et al, 2020).

\section{Policy}

Titmuss (in Suharto, 2010: 7) defines policy as "principles governing actions directed at certain objectives". Policy according to Titmuss is always problem-oriented and action-oriented. Thus it can be stated that the policy is a provision that contains principles to direct the ways of acting that are planned and consistent in achieving certain goals. Jones (in Abidin, 2012: 6) describes some of the contents of the policy, including:

1. The first policy content is the goal. What is meant is a certain goal that is desired to be achieved (the desired ends to be achieved); not something that is just desired.

2. Plans or proposals that are a particular tool or way to achieve it.

3. Certain programs or methods that have been approved and approved to achieve the intended purpose.

4. Decisions, namely certain actions taken to set goals, make and adjust plans, and implement and evaluate programs.

5. Impact (effect), the impact arising from a program in society.

\section{Prior Research}

Previous research that has a theme in accordance with the research studied is presented in the following table:

Table 2.1

Prior Research

\begin{tabular}{|c|c|c|c|c|}
\hline No & Author & Title & Year & Result \\
\hline 1 & $\begin{array}{l}\text { Siska } \\
\text { Maulina } \\
\text { Saputri }\end{array}$ & $\begin{array}{l}\text { Chicken Farming } \\
\text { Business In The Middle } \\
\text { Of Community } \\
\text { Settlements Judging } \\
\text { From Islamic Business } \\
\text { Ethics }\end{array}$ & 2018 & $\begin{array}{l}\text { Mr. Bukhori's chicken farm located in the } \\
\text { village of Sumbersari, Bantul Metro, } \\
\text { South Jakarta is not in accordance with } \\
\text { the principles of business ethics in } \\
\text { conducting his business because the } \\
\text { community around the livestock business } \\
\text { feels disturbed by the waste generated } \\
\text { from the livestock business in the form of } \\
\text { chicken manure. }\end{array}$ \\
\hline
\end{tabular}




\begin{tabular}{|c|c|c|c|c|}
\hline 2 & $\begin{array}{l}\text { Sri } \\
\text { Nawatmi }\end{array}$ & $\begin{array}{l}\text { In Business Ethics } \\
\text { Islamic perspective }\end{array}$ & 2010 & $\begin{array}{l}\text { Many companies have not implemented } \\
\text { ethics in } \\
\text { business, so what happens is that } \\
\text { competition is not balanced between } \\
\text { strong investors with weak investors, } \\
\text { there are many injustices, the emergence } \\
\text { of moral hazard, bribery and others. Its } \\
\text { Islamic business ethics makes the prophet } \\
\text { a successful trader. }\end{array}$ \\
\hline 3 & Muryani & $\begin{array}{l}\text { Impact of Avian } \\
\text { Influenza on the } \\
\text { Economy: } \\
\text { Review of National } \\
\text { Environmental, Social } \\
\text { and Economic Aspects }\end{array}$ & 2013 & $\begin{array}{l}\text { Decreased meat sector production } \\
\text { poultry (traditional and medium-large) } \\
\text { and the egg sector have an impact on } \\
\text { micro and macroeconomic aspects. Tax } \\
\text { reduction. At a macro level, there was a } \\
\text { decline in GDP, a decline in investment, a } \\
\text { decline in the price of capital and labor. } \\
\text { Likewise the interest rate has decreased, } \\
\text { but the inflation rate has not changed. }\end{array}$ \\
\hline 4 & Muryani & $\begin{array}{l}\text { Government Policies in } \\
\text { the Framework of } \\
\text { Economic Recovery } \\
\text { And Its Relation to the } \\
\text { Outbreak of Bird Flu }\end{array}$ & 2015 & $\begin{array}{l}\text { Increased productivity and the presence of } \\
\text { government policies have an impact on } \\
\text { the micro and economic aspects as a } \\
\text { whole. On a micro scale, there was an } \\
\text { increase in production and falling prices } \\
\text { in the meat, poultry, eggs, other livestock, } \\
\text { restaurant and sector sectors } \\
\text { hospitality. While in the export and } \\
\text { import aspects there was an increase in } \\
\text { exports and a decrease in imports in } \\
\text { almost all sectors. Likewise, there was an } \\
\text { increase in consumption by all groups of } \\
\text { households due to an increase in income } \\
\text { by } \\
\text { entire household and company groups. } \\
\text { Government revenue has also increased } \\
\text { due to an increase in taxes from } \\
\text { households and companies. }\end{array}$ \\
\hline 5 & $\begin{array}{l}\text { Edi } \\
\text { Basuno }\end{array}$ & $\begin{array}{l}\text { Review of Impacts of } \\
\text { Plague and Control } \\
\text { Policy } \\
\text { Avian Influenza in } \\
\text { Indonesia }\end{array}$ & 2008 & $\begin{array}{l}\text { Indonesia needs reliable human } \\
\text { resources, adequate funding allocation } \\
\text { and strong political commitment, in } \\
\text { addition to excellent coordination }\end{array}$ \\
\hline 6 & $\begin{array}{l}\text { Septi Budi } \\
\text { Utami }\end{array}$ & $\begin{array}{l}\text { Strategies of } \\
\text { Entrepreneurs Know To } \\
\text { Face } \\
\text { Competition Between } \\
\text { Entrepreneurs } \\
\text { Perspective of Islamic } \\
\text { Business Ethics (Study } \\
\text { in the Tofu Industry } \\
\text { Village of Limbangan, } \\
\text { Kutasari, Purbalingga) }\end{array}$ & 2016 & $\begin{array}{l}\text { Entrepreneurs know in the face of } \\
\text { competition between entrepreneurs in } \\
\text { the village of balance is carried out in the } \\
\text { form of price fixing, place placement } \\
\text { marketing, promotions carried out, and } \\
\text { the production process. Based on the } \\
\text { analysis of the writer's strategy the } \\
\text { entrepreneur knows in the face of } \\
\text { competition between entrepreneurs is in } \\
\text { accordance with the values in Islamic } \\
\text { business ethics. }\end{array}$ \\
\hline
\end{tabular}




\begin{tabular}{|l|l|l|l|l|}
\hline 7 & $\begin{array}{l}\text { Kwik } \\
\text { Kian Gie }\end{array}$ & $\begin{array}{l}\text { RI Government } \\
\text { Economic Policies: } \\
\text { Review of Business } \\
\text { Ethics }\end{array}$ & 2003 & $\begin{array}{l}\text { Business ethics is still low due to the } \\
\text { practice of KKN that is still lasting. }\end{array}$ \\
\hline
\end{tabular}

Source: Data processed, 2020

\section{Theoretical Framework}

The COVID-19 pandemic outbreak that occurred in Indonesia caused the government to set policies by issuing Government Regulation in Lieu of Law No. 1 of 2020 (PERPPU 01/2020) on 31 March 2020 on the Ministry of Foreign Affairs page, en we can see that there are many restrictions that narrow space business actors such as restricting export-import. Other government policies regarding the appeal of physical distancing, work, study and worship at home, to the prohibition of activities that cause a crowd would certainly make the economic wheel almost stopped (Sugianto, 2020). For this reason, the policies imposed by the government must be precise so that there is no tyranny. Furthermore, even for business owners they must make good communication so as not to lose consumers can streamline employee performance and can boost the country's economy. So the authors make the following theoretical research framework:

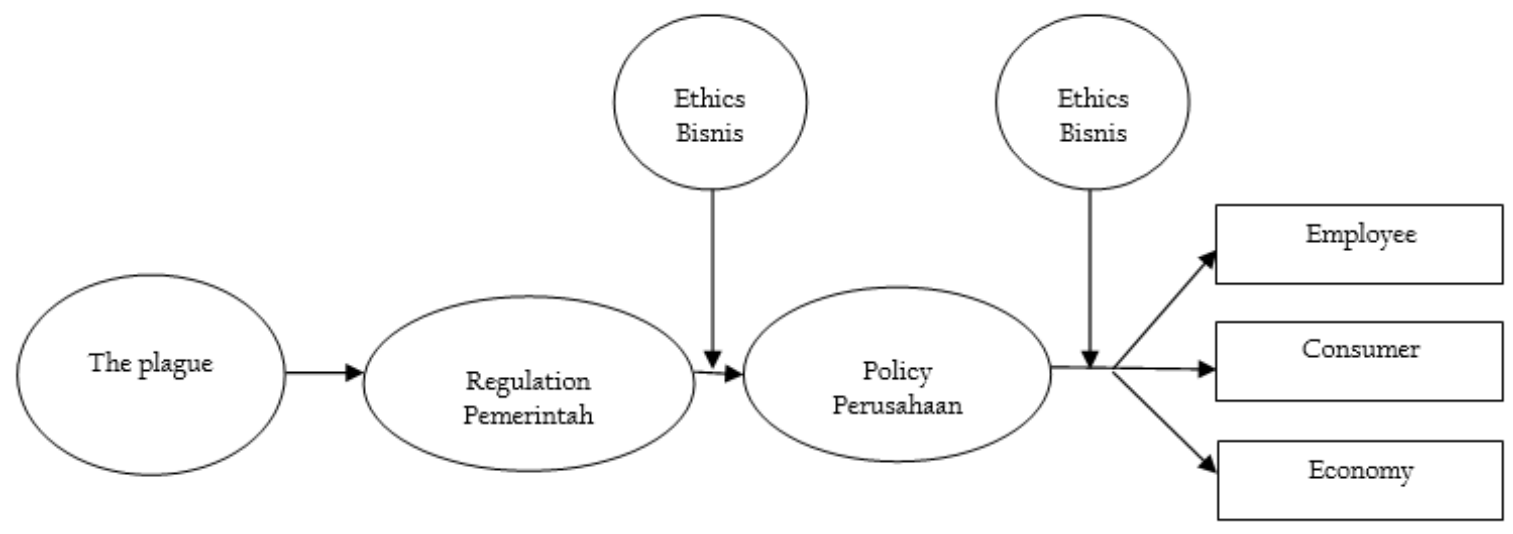

\section{Impact of the Covid-19 Outbreak}

Quoted from Bisnis.com (2020) Corona virus first spread in the Wuhan Region, China in December 2019. Since January 23, 2020 China has imposed a lockdown policy to suppress the spread of the virus that has infected 81,171 people. This policy is carried out by stopping air and train travel and restricting private vehicle trips. In addition the government also prohibits large gatherings and prevents people from leaving their homes. With this policy the China Statistics Bureau reported that the economy in the first quarter of 2020 contracted or grew negative $-6.8 \%$ year-on-year (YoY). This is the first negative economic growth YoY since 1992 (Setiaji, 2020). Not only affecting the country, this virus quickly spread to various parts of the world, causing panic, including in Indonesia.

Not long after, on 2 March 2020 the President of the Republic of Indonesia announced the first COVID-19 case in Indonesia. After this news spread in mid-March there were some hoax news stating that there would be a lockdown for all regions of Indonesia. However, KOMINFO on their official webpage (kominfo.go.id) states the fact that the government only calls for people to limit their activities to travel. On March 31, 2020, President Joko Widodo signed Government Regulation No. 21 of 2020, which governs large-scale social restrictions in response to COVID-19, which allows local governments to limit the movement of people and goods in and out of their respective regions as long as they has received permission from the relevant ministry. The impact of the corona issue relating to business actors in Indonesia is as follows:

1. Hoarding

Mask prices are generally in the range of 20-30 thousand rupiah for one box, but Newc.detik.com reports an increase to reach 300 thousand rupiah for one box maxer. This unreasonable price makes some people difficult to get a mask, the severity of scarcity and the 
increase in prices is caused by a hoarding of masks. These hoarders make a profit of up to 250 million rupiah a day, which is their reason for hoarding and distributing masks to places that they shouldn't have to pay attention to aspects of the common good.

2. Panic buying

The announcement of a positive patient of COVID-19 in Indonesia on March 2, 2020, caused residents of the capital to take action in a supermarket raid. Quoted from Katadata.co.id (2020) although stock can still be obtained, but this phenomenon continues to occur. Of course the impact will be quite detrimental where there will be the threat of inflation and scarcity of goods.

3. Mass layoffs

Kompas.com reports at least the number of layoffs that have occurred since the COVID-19 outbreak has reached 2 million people. Based on data from the Ministry of Manpower as of April 20, 2020, there were 2,084,593 workers from 116,370 companies laid off. While the lockdown policy continues to apply, this of course makes many people find it difficult to fulfill their integrity when they have to be different at home.

\section{Discussion}

From the results of the above research we can see that the company faces various kinds of obstacles caused by COVID-19. From government positions, especially those related to business people. Policies made by the government and companies must adhere to Islamic business ethics in accordance with the needs and culture, namely:

1) Transparent platform

Gie (2003) explains the low level of business when in government is due to the presence of $\mathrm{KKN}$, while KKN occurs because there is no transparency or a clear platform for the public to access information. Therefore, in this situation, both the government and companies must establish clear standards regarding targets and information regarding policies. For example, in the case of unilateral dismissal of employees is very contrary to government policies that prohibit the dismissal of the company at the time of the outbreak (Fajar, 2020). However, there are still many companies that commit violations. So the government should directly appoint which sectors are prohibited from firing and provide solutions.

2) Standard setting

Hoarding can occur because the commodity is produced only by a handful of people. So that entrepreneurs can continue to maintain their business policies with clear standards of production standards that conform to health standards. Reflecting on Utami (2006), even with the same sect as a clear standard, each company will not be stockpiled so that consumers can enjoy products at reasonable prices and are reasonably safe. Like the policy on the use of cloth masks, palembangtribunnews.com reported that this proved to make hoarding masks not so burdensome to the community because the community's needs had been met.

3) Educative public relations

Definition of Public Relations according to the International Public Relations Association (IPRA) in Rumanti (2005: 11), public relations is a management function of the mindset that is planned and carried out continuously by organizations, public and private institutions used to obtain and foster mutual understanding, sympathy and support from those who are related and thought to be related, by assessing their public opinion, with the aim to link policies and management wherever possible, in order to achieve more productive cooperation, and to fulfill common interests more efficiently, with planned and widespread lighting activities. Examples of things the company does is add a warning to wash the product before it is used to avoid viruses etc. By implementing this method, it is expected that the people will not harm consumers and their employees while maintaining the safety and health of the community.

\section{CONCLUSION AND RECOMMENDATION}

Pandemic outbreaks such as COVID-19 are international disasters that cannot be predicted when they come. The handling that will be taken by each country will vary according to their needs and culture. But to avoid panic and economic weakness that will occur, the government must 
cooperate with domestic business people in communicating and making policies to deal with outbreaks. Because the policies taken by the government will have an impact on business actors.

From this research it can be seen that based on literature review which has been used as a source of data, the author's suggestion regarding the value of Islamic business ethics that must be considered by the government and business actors in making policy is first, the establishment of a clear and transparent information platform. Second, setting standards on the activities and products of entrepreneurs that are in accordance with health regulations to control the needs of community products. And finally, conducting an educational public relations where business actors in particular can form a recovery image on their products, which in addition can spread health regulations that can reduce the spread of epidemics.

This research has not been supported with real data from the situation on the ground because it is only based on literature review from reliable sources. It would be better if there is further research that can be proven with statistics from field data.

\section{REFERENCES}

A Safrizal Z, Danang Insita Putra, Safriza Sofyan and Bimo (2020). General Guidelines on Facing the COVID-19 PANDEMY for Local Governments: Prevention, Control, Diagnosis and Management. Ministry of Home Affairs Work Team to Support Covid-19 Task Force.

A Suharto, Eddie. (2010). Public Policy Analysis. Bandung: CV Alfabeta.

Alfons, Matthew. (2020). Utilizing the Corona Issue, the Mask Hoarding Factory in North Jakarta Earns Rp 250 Million / Day. News.https://news.detik.com/berita/d-4918419/ utilized-isucorona-pabrik- hoarding-mask-in-jakut-raup-rp-250-jutahari.Friday, 28 Feb 2020 13:51 WIB.

Aria, Pingit (2020). Panic Buying and Corona Virus Threat Infect Retail Business. News. https://katadata.co.id/telaah/2020/03/17/panic-buying-dan-ancaman-virus-corona-jangkitibisnis-retail 03/17/2020, 20.30 WIB

Aziz, Abdul. (2013). Islamic Business Perspective: Implementing Islamic Ethics for the Business World. Bandung: Alfabeta

Basuno, Edi. (2008). Review of the Impact of Plague and Avian Influenza Control Policies in Indonesia. Journal. Agricultural Policy Analysis, Volume 6 No. 4, December 2008: 314 334

Buana, Examination fund. (2020). Analysis of the Behavior of Indonesian Communities in Dealing with the Corona Virus Pandemic (Covid-19) and Tips for Maintaining Mental Welfare. REGARDS; Journal of Social \& Culture Syar-i FSH UIN Syarif Hidayatullah Jakarta Vol. 7 No. 3 (2020), pp.217-226, DOI: 10.15408 / sjsbs.v7i3.15082

Budiartie, Gustidha (2020). Revealed! The First Corona Case Occurred in China November 17. News.https: //www.cnbcindonesia.com/lifestyle/20200511134907-33-157600/exposedcases-corona-first-happened-in-china-17-november. 11 May 2020 14:11

Djakfar, Muhammad. (2012) .Etika Bisnis. Jakarta: Penebar Plus

Fahmi, Irham. (2013). Organizational behavior. Theory, Applications and Cases. Bandung: Alfabeta

Fajar, Taufik. Fact of Prohibiting Layoffs in the Middle of Corona Virus Pressure. News. https://economy.okezone.com/read/2020/03/20/320/2186568/fakta-panganangan-phk-ditengah-Press-virus-corona. Week 22 March 2020 06:08 WIB

Fischer, Rebecca (2020). What's the difference between a pandemic, epidemic and outbreak ?. Web Journal.https: //www.sunjournal.com/2020/03/15/whats-the-difference-between-pandemicepidemic-and-outbreak/.dip 15 March 2020, Updated March 17, 2020.

Haryadi, Soegeng (2020). Lose Compete with Fabric Masks, Finger Bite Mask Hoarders.https: //palembang.tribunnews.com/2020/05/11/kalah-aing- with-masker-cain- penimbun-maskergigit-jari $?$ Page = all. Monday, May 11, 2020, 7:59

Hidayah, Novita Sa' adatul. (2015). Business Competition in the Traders of the Ganefo Mranggen Demak Market in the Review of Islamic Business Ethics. Encryption, UIN Walisongo, Semarang 
Kwik Kian Gie. (2003). Economic Policy of the Government of the Republic of Indonesia: A Review of Business Ethics. Paper Presented at the 26th Pilgrim National Conference Forum Muhammadiyah in Padang, October 3, 2003

Miranti, Ade. (2020) Impact of Covid-19, Menaker: More than 2 Million Workers Lay-Off and Layed Off. News. https://money.kompas.com/read/2020/04/23/174607026/dampak-covid19-menaker-more-from-2-juta-worker-di-phk-and-rushed. 04/23/2020, 17:46 WIB

Muryani. (2013). Impact of Bird Flu on the Economy: Overview of National Environmental, Social and Economic Aspects. Dissertation, ITB

Muryani. (2015). Government Policy in the Context of Economic Recovery and Its Relation to the Outbreak of Avian Influenza. Applied Quantitative Economic Journal Vol. 8 No. August 2, 2015

Nawatmi, Sri. (2010). Business Ethics in Islamic Perspective. Economic Focus (FE), April 2010, pp. 50 - 58 Vol. 9, No.1

Nugroho, Aprianto Cahyo. (2020). Finally, China removed the lockdown in Wuhan on April 8. News.https: //kabar24.bisnis.com/read/20200324/19/1217401/ finally-china-cabutlockdown-di- wuhan-8-april-upcoming.March 2020 | 12:42 WIB

Rohmana K Pure. (2020). UPDATE Corona Virus Distribution in Indonesia Saturday (06/13/2020): 4 Provinces Record New Cases in the Top 100. Berita.https: //ternate.tribunnews.com/2020/06/13/update -sebar-virus-corona-in-indonesia-saturday1362020-4-province-note-case-new-above-100 accessed on 13 June 2020 16:34

Saputri, Siska Maulina. (2018). Chicken Farming Business in the Middle of Community Settlements Judging from Islamic Business Ethics.

Setiaji, Hidayat. (2020) .Chinese economy $-6.8 \%$ ? Ah, that's the story yesterday. News.https: //www.cnbcindonesia.com/news/20200417142113-4-152709/ekonomi-china-68-ah-itu-kancerita-kemarin.17 April 2020 14:33

Utami, Septi Budi. (2016). Tofu Entrepreneurs Strategies To Face Competition Between Entrepreneurs Perspective of Islamic Business Ethics (Study on Know Village Industry in Limbangan, Kutasari, Purbalingga Village). 